\title{
PENERAPAN PEMBELAJARAN MODEL ELICITING ACTIVITIES (MEAS) UNTUK MENINGKATKAN KEMAMPUAN BERPIKIR KREATIF MATEMATIS SISWA
}

\author{
Hedi Budiman \\ FKIP UnIVERsitas SURYAKANCANA \\ hedi@unsur.ac.id \\ KHAIRUNNISA NOOR SYAYYIDAH \\ FKIP UNIVERSitAs SURYAKANCANA \\ nsy11nisa@gmail.com
}

\begin{abstract}
Abstrak
Penelitian ini bertujuan untuk mengetahui peningkatan kemampuan berpikir kreatif matematis siswa dengan menggunakan pendekatan Model Eliciting Activities (MEAs) dan bagaimana sikap siswa terhadap pembelajaran dengan pendekatan Model Eliciting Activities. Metode penelitian yang digunakan adalah quasi experiment dengan desain penelitian nonequivalent control group design. Penelitian ini dilaksanakan di SMP Negeri Cianjur dengan populasi seluruh kelas VII. Sampel yang digunakan yaitu kelas VII-4 sebagai kelas kontrol dan kelas VII-9 sebagai kelas eksperimen. Instrumen yang digunakan adalah instrumen tes berupa soal uraian kemampuan berpikir kreatif matematis dan instrumen non tes berupa angket skala sikap. Hasil penelitian ini menunjukkan bahwa peningkatan kemampuan berpikir kreatif matematis siswa yang menggunakan pendekatan Model Eliciting Activities (MEAs) lebih baik daripada siswa yang menggunakan pendekatan saintifik dan sebagian besar sikap siswa positif terhadap pembelajaran dengan pendekatan Model Eliciting Activities (MEAs).
\end{abstract}

Kata kunci: Model Eliciting Activities, Pendekatan Pembelajaran, Berpikir Kreatif Matematis

\begin{abstract}
The research aims to determine the enhancement of students' mathematical thinking skills using the Model Eliciting Activities (MEA) approach and how students' attitudes toward the Model Eliciting Activities (MEA) approach learning. The research method used quasi experiment with research design nonequivalent control group design. This research was conducted in SMP Negeri Cianjur with population in 7th grade. The sample used class VII-4 as control class and class VII-9 as experiment class. The instrument was essay question to measure mathematical creative thinking ability and a questionnaire of attitude scale as non-test instrument. The results showed that the enhancement of students' mathematical creative thinking ability using the Model Eliciting Activities (MEA) approach was better than students using a scientific approach and most students attitude was positive response toward the Model Eliciting Activities (MEA) approach.
\end{abstract}

Keywords: Model Eliciting Activities, Learning Approach, Mathematical Creative Thinking

\section{Pendahuluan}

Matematika merupakan salah satu bidang pengetahuan yang menjadi pelajaran wajib di setiap satuan pendidikan. Matematika dapat menumbuh-kembangkan kemampuan siswa dalam berpikir kritis, kreatif, logis, dan sistematis dalam mengkomunikasikan suatu gagasan atau ide untuk memecahkan masalah. Masalah dalam hal ini berarti soal. Siswa 
yang dapat menguasai dan terampil menyelesaikan masalah dengan tahapan-tahapan tertentu dapat dikatakan menguasai matematika. Penguasaan tahapan-tahapan penyelesaian masalah inilah akhirnya menjadi target berhasil atau tidaknya seorang guru mengajar matematika Hamzah, 2014.

Usman menyatakan bahwa untuk memecahkan masalah matematika, terutama soalsoal non rutin, siswa memerlukan kemampuan berpikir kreatif matematis Usman, 2016. Dengan memiliki kemampuan berpikir kreatif matematis, siswa mampu memunculkan banyak ide, mampu memandang masalah dari berbagai sudut pandang serta mencari pemecahan masalah dengan berbagai cara. Menurut Amalia dkk berpikir kreatif merupakan suatu proses yang digunakan ketika mendatangkan atau memunculkan suatu ide baru Amalia et al., 2015. Izzati menjelaskan bahwa orang yang memiliki kemampuan berpikir kreatif tidak hanya mampu menghadapi masalah-masalah non rutin, tetapi juga mampu melihat berbagai alternatif dari pemecahan masalah Izzati, 2009.

Berdasarkan penelitian yang dilakukan oleh Lambertus sebagian siswa mengalami kesulitan dalam mengemukakan ide penyelesaian soal, menggambarkan situasi soal atau menggunakan model informal untuk menemukan jawaban yang formal, dan membuat ide penyelesaian soal yang berkaitan dengan materi, serta mengambil kesimpulan untuk menentukan jawaban akhir soal Lambertus, 2009. Hasil penelitian yang dilakukan oleh Risnanosanti menyatakan bahwa kemampuan berpikir kreatif matematis siswa masih kurang dalam menyelesaikan soal-soal kebaruan karena tidak terbiasa menyelesaikan permasalahan dengan cara mereka sendiri Risnanosanti, 2010. Sementara itu hasil penelitian yang dilakukan oleh Kartini menyatakan bahwa kemampuan berpikir kreatif matematis siswa belum memuaskan, sebagian siswa masih banyak mengalami kesulitan terutama dalam memberikan jawaban dengan banyak cara, beragam dan dengan caranya sendiri Kartini, 2011.

Pada umumnya pembelajaran matematika di sekolah khususnya siswa SMP ditekankan pada hafalan atau pengertian bukan pada pemahaman serta pembelajaran yang bertujuan untuk mencari jawaban melalui satu cara penyelesaian. Soal-soal kurang melatih kemampuan berpikir tingkat tinggi siswa seperti berpikir kritis dan berpikir kreatif. Dalam pembelajaran guru kurang mengaitkan dengan kehidupan sehari-hari.

Sebagai upaya memfasilitasi atau mengembangkan kemampuan siswa dalam berpikir kreatif, guru harus dapat menciptakan suasana belajar yang membuat siswa aktif sehingga siswa dapat menyampaikan pemikiran dan kreativitasnya secara bebas dan siswa dapat menerima atau mengetahui pengetahuan baru melalui konfirmasi yang diberikan guru atas pemikirannya. Salah satu pembelajaran yang dapat digunakan adalah pendekatan Model Eliciting Activities (MEAs).

Pendekatan Model Eliciting Activities (MEAs) merupakan pendekatan pembelajaran yang memfokuskan aktivitas siswa untuk mendapatkan atau memperoleh penyelesaian dari masalah nyata yang diberikan melalui proses mengaplikasikan prosedur matematis untuk membentuk sebuah model matematika. Masalah yang realistis merupakan ciri khas dari MEAs. Dalam pembelajaran MEAs, siswa dihadapkan dengan permasalahan yang bermakna dan relevan dengan kehidupan sehari-hari mereka. Dengan prinsip realitas ini, pembelajaran MEAs melatih kemampuan siswa dalam menganalisis situasi secara kritis dan kreatif sehingga dapat memecahkan masalah yang dihadapinya Akhmad, 2014.

Menurut Istianah pembelajaran matematika dengan pendekatan MEAs merupakan suatu alternatif pendekatan yang berupaya membuat siswa dapat secara aktif terlibat dalam proses pembelajaran matematika di kelas Istianah, 2013. Dengan terlibatnya siswa secara aktif dalam proses pembelajaran maka diharapkan kemampuan berpikir kreatif siswa dalam matematika akan terus meningkat dan terlatih dengan baik. Menurut Ayuningtyas melalui MEAs, siswa berulang kali mengungkapkan, menguji, dan memperbaiki atau merevisi cara berpikir mereka untuk menghasilkan sebuah model terstruktur dan paling efektif dan efisen untuk memecahkan masalah yang diberikan Ayuningtyas et al., . 
Selain itu, mengingat kurikulum yang diterapkan saat ini adalah kurikulum 2013, maka pendekatan pembelajaran yang dilakukan di sekolah yaitu pendekatan saintifik. Modul Diklat Kurikulum 2013 menyatakan bahwa pendekatan saintifik dimaksudkan untuk memberikan pemahaman kepada peserta didik dalam mengenal, memahami berbagai materi menggunakan pendekatan ilmiah, bahwa informasi bisa berasal dari mana saja, kapan saja, tidak bergantung pada informasi searah dari guru [Majid, 2014].

Hasil penelitian yang dilakukan oleh Hanifah menyatakan bahwa pencapaian dan peningkatan kemampuan representasi matematis siswa yang memperoleh pembelajaran MEA dengan pendekatan saintifik lebih baik daripada siswa yang memperoleh pembelajaran dengan pendekatan saintifik Hanifah, 2016]. Istianah menyatakan bahwa peningkatan kemampuan berpikir kreatif matematis siswa kelompok atas dan kelompok bawah yang memperoleh pembelajaran matematika dengan pendekatan MEAs lebih baik secara signifikan daripada siswa kelompok atas dan kelompok bawah yang mendapatkan pembelajaran ekspositori.

\section{Metode Penelitian}

Penelitian ini menggunakan metode eksperimen dengan jenis penelitian quasi experimental design. Desain penelitian quasi eksperimen yang digunakan yaitu nonequivalent control group design.

Populasi dalam penelitian ini adalah seluruh siswa kelas VII di SMP Negeri Cianjur. Adapun sampel dalam penelitian ini kelas kontrol adalah kelas VII-4 yang berjumlah 38 orang (kelas yang mendapatkan pembelajaran dengan menggunakan pendekatan saintifik) dan kelas eksperimen adalah kelas VII-9 yang berjumlah 36 orang (kelas yang mendapatkan pembelajaran dengan menggunakan pendekatan MEAs). Instrumen yang digunakan adalah instrumen tes dan non-tes berupa kuesioner untuk mengukur sikap siswa terhadap pembelajaran MEAs. Pernyataan-pernyataan dalan angket dikategorikan kedalam 3 aspek yaitu sikap siswa terhadap pelajaran matematika, sikap siswa terhadap pembelajaran matematika dengan menggunakan pendekatan Model Eliciting Activities (MEAs), dan sikap siswa terhadap soal kemampuan berpikir kreatif matematis.

\section{Hasil dan Pembahasan}

\subsection{Pengetahuan Mengenai Pengertian Intrusi Air Laut}

Materi yang diajarkan pada penelitian ini adalah perbandingan. Statistik deskriptif kemampuan berpikir kreatif matematis siswa dapat dilihat pada Tabel1 1 .

Tabel 1: Statistik Deskriptif Data

\begin{tabular}{lccccccc}
\hline \multirow{2}{*}{ Statistik Deskriptif } & \multicolumn{3}{c}{ Pembelajaran Saintifik } & & \multicolumn{3}{c}{ Pembelajaran MEAs } \\
\cline { 2 - 4 } & Pretes & Post Test & N Gain & & Pretes & Post test & N Gain \\
\hline Min & 2 & 3 & 0,05 & & 2 & 4 & 0,00 \\
Maks & 15 & 21 & 0,81 & & 12 & 23 & 0,92 \\
Rata-rata & 5,13 & 11,47 & 0,3508 & & 6,11 & 14,67 & 0,499 \\
Standar deviasi & 2,896 & 4,507 & 0,1825 & & 2,806 & 5,493 & 0,260 \\
\hline
\end{tabular}

Hipotesis 1: Pencapaian kemampuan berpikir kreatif matematis siswa yang memperoleh pembelajaran MEAs lebih baik daripada siswa yang memperoleh pembelajaran saintifik.

Berdasarkan hasil uji Mann-Whitney, diperoleh nilai signifikansi sebesar 0,010. Nilai tersebut kurang dari 0,05 maka $H_{0}$ ditolak. Dengan demikian dapat disimpulkan bahwa terdapat perbedaan pencapaian kemampuan berpikir kreatif matematis siswa kelas eksperimen dan kelas kontrol. Kemudian, dengan memperhatikan nilai rerata, diperoleh 
Tabel 2: Uji Perbedaan Rerata Skor Postes Kemampuan Berpikir Kreatif Matematis

\begin{tabular}{cccc}
\hline Kelas & Rata-rata & Uji Mann-Whitney & Kesimpulan \\
\hline Kontrol & 11,47 & 0,010 & $H_{0}$ ditolak \\
Eksperimen & 14,67 & & \\
\hline
\end{tabular}

kesimpulan bahwa siswa yang memperoleh pembelajaran lebih baik daripada siswa yang memperoleh pembelajaran Saintifikl. Dengan demikian, hipotesis 1 terbukti.

Hipotesis 2: Peningkatan kemampuan berpikir kreatif matematis siswa yang memperoleh pembelajaran MEAs lebih baik daripada siswa yang memperoleh pembelajaran saintifik.

Berdasarkan Tabel 3, dapat dilihat bahwa peningkatan kemampuan berpikir kreatif matematis siswa kelas eksperimen lebih baik daripada kelas kontrol. Hal tersebut dapat terlihat pada rata-rata skor $\mathrm{N}$-Gain pada indikator keluwesan dan keaslian yang diperoleh kelas eksperimen menunjukkan peningkatan yang sedang. Sedangkan rata-rata skor $N$-Gain pada indikator keluwesan dan keaslian yang diperoleh kelas kontrol menunjukkan peningkatan yang rendah. Sementara itu, rata-rata skor $N$-Gain pada indikator kelancaran dan elaborasi yang diperoleh oleh kelas eksperimen dan kelas kontrol menunjukkan peningkatan yang sedang. Berdasarkan penjelasan di atas, dapat disimpulkan bahwa peningkatan pada setiap indikator yang dicapai kelas eksperimen lebih baik daripada kelas kontrol.

Tabel 3: Rata-Rata Skor N-Gain Setiap Indikator

\begin{tabular}{cccccc}
\hline \multirow{2}{*}{ Indikator } & \multicolumn{2}{c}{ Kelas Kontrol } & & \multicolumn{2}{c}{ Kelas Eksperimen } \\
\cline { 2 - 3 } \cline { 5 - 6 } & $N$-Gain & Interpretasi & & $N$-Gain & Interpretasi \\
\hline Kelancaran & 0,42 & Sedang & & 0,52 & Sedang \\
Keluwesan & 0,28 & Rendah & & 0,55 & Sedang \\
Keaslian & 0,29 & Rendah & & 0,44 & Sedang \\
Elaborasi & 0,41 & Sedang & & 0,44 & Sedang \\
\hline
\end{tabular}

Instrumen non tes yang digunakan dalam penelitian ini adalah angket skala sikap.

Berdasarkan hasil analisis, $83 \%$ siswa menunjukkan sikap yang positif terhadap pelajaran matematika. Sementara itu, $71 \%$ siswa menunjukkan sikap yang positif terhadap pembelajaran matematika dengan menggunakan pendekatan Model Eliciting Activities (MEAs) dan $52 \%$ siswa menunjukkan sikap yang positif terhadap soal kemampuan berpikir kreatif matematis.

Secara keseluruhan, diperoleh persentase sikap positif siswa secara keseluruhan sebesar $68 \%$ yang menunjukkan bahwa sebagian besar siswa bersikap positif setelah mendapatkan pembelajaran matematika dengan pendekatan Model Eliciting Activities (MEAs). Sedangkan 32\% lainnya menunjukkan bahwa hampir setengahnya dari jumlah siswa bersikap negatif setelah mendapatkan pembelajaran matematika dengan pendekatan Model Eliciting Activities (MEAs).

Pada penelitian ini, salah satu hal yang mempengaruhi adanya perbedaan peningkatan kemampuan berpikir kreatif matematis siswa kelas eksperimen dan kelas kontrol yaitu pemberian perlakuan atau pembelajaran yang berbeda. Pembelajaran yang dilakukan pada kelas kontrol menggunakan pendekatan saintifik, pembelajaran yang biasa dilakukan sehari-hari atau seperti biasanya. Sedangkan pada kelas eksperimen, dilakukan pembelajaran dengan pendekatan Model Eliciting Activities (MEAs) dimana siswa belajar se- 
Tabel 4: Sikap Siswa secara Keseluruhan

\begin{tabular}{|l|c|c|l|}
\hline Aspek yang Diukur & \multicolumn{2}{|c|}{ Rata-rata Persentase Sikap } & Interpretasi \\
\cline { 2 - 4 } & Positif & Negatif & \\
\hline $\begin{array}{l}\text { Sikap Siswa terhadap Pela- } \\
\text { jaran Matematika }\end{array}$ & $83 \%$ & $17 \%$ & Pada Umumnya Positif \\
\hline $\begin{array}{l}\text { Sikap Siswa terhadap } \\
\begin{array}{l}\text { Pembelajaran Matematika } \\
\text { dengan Menggunakan Pen- } \\
\text { dekatan Model Eliciting }\end{array}\end{array}$ & $71 \%$ & $29 \%$ & Sebagian Besar Positif \\
Activities (MEAs) & & & \\
\hline $\begin{array}{l}\text { Sikap Siswa terhadap Soal } \\
\text { Kemampuan Berpikir Kre- } \\
\text { atif Matematis }\end{array}$ & $52 \%$ & $48 \%$ & Sebagian Besar Positif \\
\hline Rata-rata total & $68 \%$ & $32 \%$ & Sebagian Besar Positif \\
\hline
\end{tabular}

cara berkelompok. Pada kelas eksperimen, siswa dibiasakan untuk berbagi dan bertukar pendapat dengan temannya dalam menyampaikan lebih banyak ide untuk memecahkan masalah. Semua siswa mendapatkan kesempatan yang sama untuk mengemukakan atau menyampaikan hasil pengerjaannya di depan kelas. Selain itu, pada setiap pertemuan siswa mendapatkan LK sebagai bahan atau sumber belajarnya. Melalui LK tersebut siswa dapat membuat model atau langkah-langkah untuk menyelesaikan masalah. Siswa terbiasa untuk membaca masalah dan mulai memikirkan bagaimana langkah yang tepat yang harus digunakan untuk memecahkan masalah tersebut. Dengan adanya LK tersebut siswa merasa dirinya memiliki kesempatan untuk menyampaikan atau mengeluarkan idenya terkait penyelesaian yang harus dilakukan sehingga siswa cenderung aktif dalam proses pembelajaran baik itu untuk bertanya ataupun mengemukakan pendapatnya. Dengan demikian, adanya perbedaan aktivitas dan suasana dalam pembelajaran tersebut dapat mempengaruhi peningkatan kemampuan berpikir kreatif matematis yang dicapai kelas kontrol dan kelas eksperimen.

\section{Simpulan dan Saran}

Berdasarkan hasil penelitian dan pembahasan, dapat disimpulkan bahwa peningkatan kemampuan berpikir kreatif matematis siswa yang menggunakan pendekatan Model Eliciting Activities (MEAs) lebih baik daripada siswa yang menggunakan pendekatan saintifik. Selain itu, sebagian besar sikap siswa setelah mendapatkan pembelajaran dengan pendekatan Model Eliciting Activities (MEAs) adalah positif.

Dalam penelitian ini materi yang digunakan adalah materi perbandingan. Untuk penelitian selanjutnya disarankan untuk menggunakan pendekatan Model Eliciting Activities (MEAs) dengan memilih materi, kemampuan matematis, dan jenjang pendidikan yang berbeda. Pembelajaran dengan menggunakan pendekatan Model Eliciting Activities (MEAs) memerlukan waktu yang relatif lama dalam proses pembelajarannya sehingga diperlukan perencanaan dan persiapan yang matang.

\section{Referensi}

[Akhmad, 2014] Akhmad, G. P. A. (2014). Efektivitas pembelajaran matematika dengan pendekatan model-eliciting activities (meas) pada materi persamaan dan pertidaksamaan linear satu variabel di kelas vii-a smp negeri 1 lamongan. MATHEdunesa, 3(2). 
[Amalia et al., 2015] Amalia, Y., Duskri, M., and Ahmad, A. (2015). Penerapan model eliciting activities untuk meningkatkan kemampuan berpikir kreatif matematis dan self confidence siswa sma. Jurnal Didaktik Matematika, 2(2).

[Ayuningtyas et al., ] Ayuningtyas, W. et al. Pengaruh pendekatan model eliciting activities (mea;) terhadap kemampuan berpikir kritis dan kreatif matematis siswa.

[Hamzah, 2014] Hamzah, A. (2014). Perencanaan dan strategi pembelajaran matematika. Jakarta: Rajawali Pers.

[Hanifah, 2016] Hanifah, H. (2016). Penerapan pembelajaran model eliciting activities (mea) dengan pendekatan saintifik untuk meningkatkan kemampuan representasi matematis siswa. Kreano, Jurnal Matematika Kreatif-Inovatif, 6(2):191-198.

[Istianah, 2013] Istianah, E. (2013). Meningkatkan kemampuan berpikir kritis dan kreatif matematik dengan pendekatan model eliciting activities (meas) pada siswa sma. Infinity Journal, 2(1):43-54.

[Izzati, 2009] Izzati, N. (2009). Berpikir kreatif dan kemampuan pemecahan masalah matematis: Apa, mengapa, dan bagaimana mengembangkannya pada peserta didik. In Prosding Seminar Matematika dan Pendidikan Matematika. Bandung, volume 19.

[Kartini, 2011] Kartini (2011). Peningkatan Kemampuan Berpikir Kritis dan Kreatif serta Belief Matematis Siswa Sekolah Menengah Atas Melalui Pembelajaran Inkuiri Model Alberta.

[Lambertus, 2009] Lambertus (2009). Pentingnya Melatih Keterampilan Berpikir Kritis dalam Pembelajaran Matematika di SD.

[Majid, 2014] Majid, A. (2014). Implementasi Kurikulum 2013.

[Risnanosanti, 2010] Risnanosanti (2010). Kemampuan Berpikir Kreatif Matematis dan Self-Efficasy Terhadap Matematika Siswa Sekolah Menegah Atas (SMA) dalam Pembelajaran Inkuiri.

[Usman, 2016] Usman, M. R. (2016). Pembelajaran inkuiri model alberta untuk meningkatkan kemampuan berpikir kreatif matematis siswa smp. Delta-Pi: Jurnal Matematika dan Pendidikan Matematika, 3(2). 